\title{
HOW MUCH DO WE KNOW ABOUT THE ROLE OF VITAMIN D IN THE PATHOGENESIS OF SYSTEMIC LUPUS ERYTHEMATOSUS
}

\author{
Maria Radanova, Bogdan Roussev, Diana Ivanova \\ Department of Biochemistry, Molecular Medicine and Nutrigenomics, \\ Medical University of Varna
}

\begin{abstract}
Vitamin D is an essential steroid hormone. The role of Vitamin D in mineral metabolism and skeletal health as related to calcium homeostasis is well established. In addition to this role, vitamin $D$ has been recently accepted also as immune modulator and thus it could be possibly implicated in the pathogenesis of systemic lupus erythematosus (SLE). This review focuses on the question: „Is vitamin D deficiency involved in the pathogenesis of SLE or is it a consequence of the disease state?" and comments the known positive effects of vitamin D supplementation on SLE disease activity.
\end{abstract}

Keywords: vitamin D, systemic lupus erythematosus (SLE)

\section{INTRODUCTION}

Vitamin D is a liposoluble steroid hormone formed by cyclopentane perhydro-phenanthrene ring system. Two physiological active forms exist in nature, 1,25 -dihydroxyergocalciferol $\left(1,25(\mathrm{OH})_{2} \mathrm{D}_{2}\right)$ and 1,25-dihydroxycholecalciferol $\left(1,25(\mathrm{OH})_{2} \mathrm{D}_{3}\right)$. $1,25(\mathrm{OH})_{2} \mathrm{D}_{3}$ is the active form that is synthesized in humans and it is more effective than $1,25(\mathrm{OH})_{2} \mathrm{D}_{2}$ (20). The organs involved in vitamin D synthesis are skin, liver and kidney (18). Vitamin D synthesis begins in the skin where UVB brakes down C9-C10 bond of the precursor 7-dehydrocholesterol produc-

\footnotetext{
Address for correspondence:

Maria Radanova

Department of Biochemistry, Molecular Medicine and

Nutrigenomics,

Medical University of Varna

55 Marin Drinov Str.

9002 Varna, Bulgaria

e-mail:maria.radanova@gmail.com
}

Received: August 12, 2015

Accepted: December 15, 2015 ing cholecalciferol. Cholecalciferol is transported to the liver and submitted to hydroxylation by 25 -hydroxylase enzyme, forming 25-hydroxycholecalciferol $\left(25(\mathrm{OH}) \mathrm{D}_{3}\right)$. The final phase of the biosynthesis is in kidney where the enzyme 1-alpha-hydroxylase adds $-\mathrm{OH}$ group to position one and forms the active form $1,25(\mathrm{OH})_{2} \mathrm{D}_{3}$. Vitamin $\mathrm{D}$ is also obtained from some foods that contain ergocalciferol $\left(\mathrm{D}_{2}\right)$ or cholecalciferol $\left(\mathrm{D}_{3}\right)$, for example cod liver oil, fishes, eggs, mushrooms, etc.

The predominant form in blood is $25(\mathrm{OH}) \mathrm{D}_{3}$, with ratio $1,25(\mathrm{OH})_{2} \mathrm{D}_{3}: 25(\mathrm{OH}) \mathrm{D}_{3}$ equal to $1: 1000$. The classical role of Vitamin D is assumed to be its effect on mineral metabolism and skeletal health as related to calcium homeostasis. The regulation of calcium uptake is due to the absorption at intestinal, bone and kidney levels (29). Recent studies discovered that calcitriol played an important role in what is called non-classical vitamin D functions that included cell apoptosis/anti-proliferation, providing anticancer effects and immunomodulation (21). The non-classical vitamin $\mathrm{D}$ functions are mediated by the vitamin D receptor (VDR) localized inside the cells of most tissues. $1,25(\mathrm{OH})_{2} \mathrm{D}_{3}$ binds with VDR and the 
complex $1,25(\mathrm{OH})_{2} \mathrm{D}_{3}$-VDR with retinoid X receptor (RXRs) binds to the VDRE response elements on DNA changing the activity of different genes responsible for immunomodulation and regulation of various immunemediated processes (27).

In the current review, we aim to describe the immune modulatory effects of vitamin $\mathrm{D}$, risk factors for vitamin D deficiency in patients with systemic lupus erythematosus (SLE), role of deficiency in pathogenesis of SLE, and potential positive effects of vitamin D supplementation on SLE disease activity.

\section{VITAMIN D IMMUNE MODULATORY}

\section{EFFECTS}

The identification that the dendritic cells, which have central role to the maintenance of self-tolerance, can produce the biologically active form of vitamin $\mathrm{D}-1,25(\mathrm{OH})_{2} \mathrm{D}_{3}$ and respond to this through the VDR in autocrine way suggests that vitamin $\mathrm{D}$ is an immune modulator $(17,25,43)$. VDRs are found also in monocytes, macrophages and activated $\mathrm{T}$ and $\mathrm{B}$ cells and these cells also may convert vitamin $\mathrm{D}$ into its active form (45).

Vitamin $\mathrm{D}$ as immune modulator decreases Th1 CD4+ T cells and reduces the expression of IL2 , IFN- $\gamma$, TNF- $\alpha$, IL-12, IL- 6 and IL-17 $(23,36,30)$; increases the production of IL-4, IL-5, and IL-10, leading to the development of a Th2 T-cell population (11, 30 ); increases the number and function of regulatory T cells (Treg) (51); inhibits Th17 cells important in the development of autoimmunity $(23,36)$; inhibits monocyte differentiation into dendritic cells and blocks the stimulatory effects of $\mathrm{T}$ cells on them (8, 40); enhances monocyte differentiation into macrophages, but reduces their capacity to present antigens to lymphocytes by decreasing the expression of MHC-II molecule $(15,31)$; prevents the proliferation of activated $B$ cells and immunoglobulin production $(26,46)$; induces apoptosis in activated B cells $(16,55)$; inhibits posts switch memory B cells $(16,45,55)$; inhibits production of IFN- $\gamma$ from natural killer (NK) and T cells (60) (Figure 1).

The overall effect of $1,25(\mathrm{OH})_{2} \mathrm{D}_{3}$ is enhancement of the innate immune responses, while maintaining self-tolerance by inhibiting the adaptive immune responses. Over recent years it has been demonstrated that deficiency of $25(\mathrm{OH}) \mathrm{D}_{3}$ is related to increasing risk of autoimmune diseases such as in-

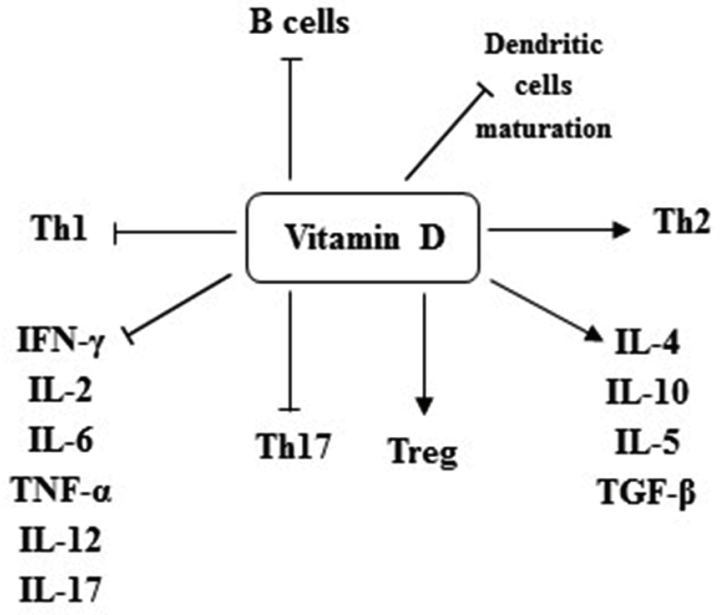

Figure 1. Vitamin D effects on the innate and adaptive immune response

sulin-dependent diabetes mellitus (IDDM), multiple sclerosis (MS), inflammatory bowel disease (IBD), rheumatoid arthritis (RA), and systemic lupus erythematosus (SLE) (36).

SYSTEMIC LUPUS ERYTHEMATOSUS ACTIVITY AND VITAMIN D LEVELS

SLE is multiorgan autoimmune disease, more prevalent in African-Americans than in Caucasians, typically involving women in childbearing age (13). SLE is characterize by the loss of tolerance to nuclear antigens, immune complexes (ICs) depositions in tissues, delayed clearance of apoptotic cells and inflammatory cytokine release.

In many cohort studies, involving a large number of participants, low serum concentrations of $25(\mathrm{OH}) \mathrm{D}_{3}$ correlated with SLE disease activity, assessed by SLEDAI (systemic lupus erythematosus disease activity index) and BILAG (British Isles Lupus Assessment Group) (3,6,7,10,12,19,24,35,38, $39,44,51,56,57,58,59)$. High titres of anti-double stranded (ds) DNA, anti-Clq antibodies and low serum levels of $\mathrm{C} 3$ and $\mathrm{C} 4$ complement are also useful tools to monitor SLE disease activity in practice. Also, significant inverse association between vitamin D levels and anti-dsDNA antibodies and direct association between vitamin $\mathrm{D}$ and complement C3 and C4 levels were established in several studies $(9,10,35,37,51)$.

This significant inverse relation between vitamin D content and the determined SLE disease activity set an open question: Is vitamin D deficiency 
involved in the pathogenesis of SLE or is it a consequence of the disease state? On one side, for SLE patients there are several risk factors for developing of $25(\mathrm{OH}) \mathrm{D}_{3}$ deficiency:

1. One of most common disease manifestations is skin photosensitivity. Patients with SLE have to avoid sun exposure because of triggering of lupus flare. The result in blocking UVB-induced synthesis of cholecalciferol in the skin. It is known that people with darker skin pigmentation who are living far from the equator are especially prone to vitamin $\mathrm{D}$ deficiency, due to the protection of melanin from harmful UVB light. This could explain, in part, the vitamin D deficiency among African-Americans (25). It is no coincidence that this ethnic group has a higher risk for development of SLE and SLE is characterized by the most severe disease manifestations.

2. Chronic treatment of SLE patients with corticosteroids and anticonvulsants may alter the vitamin $\mathrm{D}$ metabolism, may reduce vitamin D-binding protein levels or downregulate the function of VDR $(36,58)$.

3. Renal involvement in SLE patients with lupus nephritis may affect the hydroxylation step of $25(\mathrm{OH}) \mathrm{D}_{3}$ in the kidneys (47).

On the other side, immune modulatory effects of vitamin D suggest possible major specific role in SLE pathogenesis. Ritterhouse et al. (2011) found evidences in this aspect, observing that vitamin D deficiency in healthy individuals was associated with an increased presence of antinuclear antibodies antibodies (ANA) (45). This finding is interesting, because it demonstrates the relation between vitamin $\mathrm{D}$ deficiency and the immune response in the absence of any other risk factors for vitamin D deficiency, typical for SLE patients, and suggests that vitamin D deficiency in autoimmunity is not solely a consequence of the disease. Also the fact that both healthy individuals and patients with SLE, positive for ANA, have decreased vitamin D suggests that vitamin $\mathrm{D}$ deficiency is involved in the early stages of SLE pathogenesis. Most studies have found a reduction in Treg cells in lupus patients in steroid therapy (14).
The role of vitamin $\mathrm{D}$ deficiency in the pathogenesis of SLE is also shown in other studies of Ritterhouse et al. (2011) - vitamin D deficiency is associated with significant hyperactivation of B cells, autoantibody production and IFN- $\alpha$ activity in SLE patients (45). IFN- $\alpha$ is one of the key cytokines in the pathogenesis of SLE. Association between raised IFN- $\alpha$ levels and increased disease activity in SLE is known fact. The complement system plays a major and complex role in the SLE, because it may prevent and also exacerbate the disease. Sakem et al. (2003) found that low levels of $25(\mathrm{OH}) \mathrm{D}_{3}$ were directly related to the levels of IgG2 and complement component C4. In contrast these low levels of $25(\mathrm{OH}) \mathrm{D}_{3}$ were reversely associated with the levels of IgG1 and IgA and complement component C3 (49). This shows that vitamin D insufficiency may lead to a poor immune response. Interestingly Linker-Israeli et. al. (2001) found increased numbers of T, B and NK cells expressing the VDR in SLE patients compared to healthy controls. This suggests that in SLE the immune system may have increased sensitivity to vita$\min \mathrm{D}(33)$.

VITAMIN D STATUS AND METHODS FOR ANALYSIS

According to The Institute of Medicine (IOM) and the Endocrine Society's Clinical Guidelines (22). Evaluation treatment and prevention of vitamin D deficiency, the optimum values for $25(\mathrm{OH}) \mathrm{D} 3$ are at less or higher than $30 \mathrm{ng} / \mathrm{ml}$ because it is suggested that the maximum effect of vitamin $\mathrm{D}$ on calcium metabolism and bone health are in the interval between 30-40 ng/ml. Concentrations between 21-29 $\mathrm{ng} / \mathrm{ml}$ are related to vitamin D insufficiency and values lower than $20 \mathrm{ng} / \mathrm{ml}(50 \mathrm{nmol} / \mathrm{l})$ are considered vitamin $\mathrm{D}$ deficient because at this concentrations of $25(\mathrm{OH}) \mathrm{D}_{3}$ parathormone $(\mathrm{PTH})$ starts increasing.

The most important methods to determine the concentration of $25(\mathrm{OH}) \mathrm{D}_{3}$ are immunoassays and chromatographic technics. Immunoassay methods are based on using a monoclonal antibody to $25(\mathrm{OH})$ $\mathrm{D}_{3}$ with a colour product formation proportional to its concentration (enzyme-immunoassay, chemiluminiscence) or using RIA method. Chromatographic methods (HLPC, LC-MS/MS), are separative technics that isolate and quantify the $25(\mathrm{OH}) \mathrm{D}_{3}$ using mass-spectrometry. The advantages of immu- 
noassay methods are that they have relatively short technological time, they are easy to manage and are not so expensive, but serum matrix can affect the results for $25(\mathrm{OH}) \mathrm{D}_{3}$ concentrations. Chromatographic technics are referential methods with a high precision and accuracy, where the matrix cannot change the final results. However, they are very expensive, require long technological time and appropriate specific devices. Most studies reporting vitamin D levels use immunoassay methods that are not so accurate and precise as compared to chromatographic ones. This may be the cause for statistical errors and probably may explain why there are research groups that have not found an association between SLE disease activity and vitamin D status $(28,34,47,48,50,53,54)$.

\section{VITAMIN D SUPPLEMENTATION IN SLE} PATIENTS

An interesting question, which is yet to be answered, is whether supplementation with vitamin D alters the course and prognosis of SLE. Interventional studies give contradictory results for the clinical outcomes. Three clinical studies showed no significant correlations between vitamin D supplementation and SLE disease activity $(4,5,48)$. Other recent studies have found that supplementation with vitamin $\mathrm{D}$ is associated: with a decrease in disease activity $(32,41)$ and in proteinuria $(41)$; with an improvement in inflammatory and hemostatic parameters (1); with an increase in Treg cells and a reduction in Th1 and Th17 cells in a time dependent manner $(11,42,52)$; with an inhibition of B cell proliferation, induction of apoptosis and reduced differentiation into plasma cells (16); with a decrease in memory $\mathrm{B}$ cells and in anti-DNA antibodies (52).

Despite established potential beneficial effects of vitamin D in SLE, to date, vitamin D supplementation is not the standard of care for patients with SLE because there is no consensus about recommended targeted vitamin D serum levels and the optimal mode and dose of vitamin D supplementation (23). Randomized, controlled trials are needed to evaluate the type, dose, duration and any side effects of the vitamin $\mathrm{D}$ supplementation needed to achieve pharmacological and clinical efficacy.

\section{CONCLUSION}

There are unresolved questions which answers will enucleate better the causal connection between the levels of vitamin D and the pathogenesis of SLE: Which is the most appropriate phase of SLE to assess vitamin D levels (at the time of diagnosis or in remission)?; What is the cut off value of "normal" versus "insufficient" and "deficient" vitamin D levels in SLE patients?; What are the minimal beneficial levels of vitamin D in the management of SLE?; What should be the dose and duration of vitamin D supplementation?; How important are the intake of other medications, age, gender, geographic location, ethnicity, sun protective behaviour and genetic variations for the metabolism of vitamin D in SLE patients?

\section{REFERENCES}

1. Abou-Raya A, Abou-Raya S, Helmii M. The effect of vitamin D supplementation on inflammatory and hemostatic markers and disease activity in patients with systemic lupus erythematosus: a randomized placebo-controlled trial. J Rheumatol. 2013;40(3):265-72.

2. Agmon-Levin N, Theodor E, Segal RM, Shoenfeld Y. Vitamin D in Systemic and Organ-Specific Autoimmune Diseases. Clinic Rev Allerg Immunol. 2013;45:256-66.

3. Amital H, Szekanecz Z, Szücs G, Dankó K, Nagy E, Csépány T, et al. Serum concentrations of 25$\mathrm{OH}$ vitamin $\mathrm{D}$ in patients with systemic lupus erythematosus (SLE) are inversely related to disease activity: Is it time to routinely supplement patients with SLE with vitamin D? Ann Rheum Dis. 2010;69(6):1155-7.

4. Andreoli L, Dall'Ara F, Piantoni S, Zanola A, Piva $\mathrm{N}$, Cutolo M, et al. A 24-month prospective study on the efficacy and safety of two different monthly regimens of vitamin D supplementation in premenopausal women with systemic lupus erythematosus. Lupus. 2015;24(4-5):499-506.

5. Aranow C, Kamen DL, Dall'Era M, Massarotti EM, Mackay MC, Koumpouras F, et al. Randomized, Double-Blind, Placebo-Controlled Trial of the Effect of Vitamin D3 on the Interferon Signature in Patients With Systemic Lupus Erythematosus. Arthritis Rheumatol. 2015;67(7):1848-57.

6. Attar SM, Siddiqui AM. Vitamin d deficiency in patients with systemic lupus erythematosus. Oman Med J. 2013;28(1):42-7.

7. Ben-Zvi I, Aranow C, Mackay M, Stanevsky A, Kamen DL, Marinescu LM, et al. (2010) The impact of vitamin $\mathrm{D}$ on dendritic cell function in patients 
Maria Radanova, Bogdan Roussev, Diana Ivanova

with systemic lupus erythematosus. PLoS One. 2010;16;5(2):e9193.

8. Berer A, Stockl J, Majdic O, Wagner T, Kollars M, Lechner K, et al. 1,25-Dihydroxyvitamin D(3) inhibits dendritic cell differentiation and maturation in vitro. Exp Hematol. 2000; 28(5):575-83.

9. Bogaczewicz J, Sysa-Jedrzejowska A, Arkuszewska C, Zabek J, Kontny E, McCauliffe D, et al. Vitamin D status in systemic lupus erythematosus patients and its association with selected clinical and laboratory parameters. Lupus 2012;21(5):477-84.

10. Bonakdar ZS, Jahanshahifar L, Jahanshahifar F, Gholamrezaei A. Vitamin D deficiency and its association with disease activity in new cases of systemic lupus erythematosus. Lupus 2011;20(11):1155-60.

11. Boonstra A, Barrat FJ, Crain C, Heath VL, Savelkoul HF, O'Garra A. alpha,25-Dihydroxyvitamin $\mathrm{d} 3$ has a direct effect on naive CD4(+) T cells to enhance the development of Th2 cells. J Immunol. 2001;167(9):4974-80.

12. Borba VZ, Vieira JG, Kasamatsu T, Radominski SC, Sato EI, Lazaretti-Castro M. Vitamin D deficiency in patients with active systemic lupus erythematosus. Osteoporos Int. 2009;20(3):427-433.

13. Breslin LC, Magee PJ, Wallace JM, McSorley EM. An evaluation of vitamin D status in individuals with systemic lupus erythematosus. Proc Nutr Soc. 2011;70(4):399-407.

14. Buckner JH. Mechanisms of impaired regulation by CD4(+)CD25(+)FOXP3(+) regulatory T cells in human autoimmune diseases. Nat Rev Immunol. 2010;10(12):849-59.

15. Cantorna MT, Mahon BD. Mounting evidence for vitamin $\mathrm{D}$ as an environmental factor affecting autoimmune disease prevalence. Exp Biol Med.(Maywood) 2004;229(11):1136-42.

16. Chen S, Sims GP, Chen XX, Gu YY, Chen S, Lipsky PE. Modulatory Effects of 1,25-Dihydroxyvitamin D3 on Human B Cell Differentiation. J Immunol. 2007;179(3):1634-47.

17. Cutolo M, Otsa K. Review: vitamin D, immunity and lupus. Lupus. 2008;17(1):6-10.

18. Haga HJ, Brun JG, Rekvig OP, Wetterberg L. Seasonal variations in activity of systemic lupus erythematosus in a subarctic region. Lupus. 1999;8(4):269-73.
19. Hamza RT, Awwad KS, Ali MK, Hamed AI. Reduced serum concentrations of 25-hydroxy vitamin D in Egyptian patients with systemic lupus erythematosus: relation to disease activity. Med Sci Monit. 2011;17(12):CR711-8.

20. Heaney RP, Recker RR, Grote J, Horst RL, Armas LA. Vitamin $\mathrm{D}(3)$ is more potent than vitamin $\mathrm{D}(2)$ in humans. J Clin Endocrinol Metab. 2011;96(3):E44752.

21. Hewison M. Vitamin D and the immune system: new perspectives on an old theme. Endocrinol Metab Clin North Am. 2010;39(2):365-79.

22. Holick MF. 2011 Chapter 136 Vitamin D Treatment Guidelines. Evaluation treatment and prevention of vitamin D deficiency. Available from: http://www. apiindia.org/medicine_update_2013/chap136.pdf

23. Iruretagoyena M, Hirigoyen D, Naves R, Burgos PI. Immune response modulation by vitamin $\mathrm{D}$ : role in systemic lupus erythematosus. Front Immunol. 2015;6:513.

24. Kamen DL, Cooper GS, Bouali H, Shaftman SR, Hollis BW, Gilkeson GS. Vitamin D deficiency in systemic lupus erythematosus. Autoimmun Rev. 2006;5(2):114-17.

25. Kamen DL, Tangpricha V. Vitamin D and molecular actions on the immune system: modulation of innate and autoimmunity. J Mol Med. 2010;88:441-50.

26. Kamen DL. Vitamin D in Lupus. New Kid on the Block? Bull NYU Hosp Jt Dis. 2010;68(3):218-22.

27. Kaneko I, Sabir MS, Dussik CM, Whitfield GK, Karrys A, Hsieh JC, et al. 1,25-Dihydroxyvitamin D regulates expression of the tryptophan hydroxylase 2 and leptin genes: implication for behavioral influences of vitamin D. FASEB J. 2015;29(9):4023-35.

28. Kim HA, Sung JM, Jeon JY, Yoon JM, Suh CH.Kim HA, Sung JM, Jeon JY, Yoon JM, Suh CH. Vitamin $\mathrm{D}$ may not be a good marker of disease activity in Korean patients with systemic lupus erythematosus. Rheumatol Int. 2011;31(9):1189-94.

29. Kochupillai N. The physiology of vitamin D: current concepts. Indian J Med Res. 2008;127(3):256-62.

30. Kriegel MA, Manson JE, Costenbader KH. Does Vitamin D affect risk of developing autoimmune disease?: A systematic review. Semin Arthritis Rheum. 2011;40:512-53. 
31. Lemire JM. Immunomodulatory role of 1,25-dihydroxyvitamin D3. J Cell Biochem. 1992;49(1):26-31.

32. Lima GL, Paupitz J, Aikawa NE, Takayama L, Bonfa E, Pereira RM. A randomized double-blind placebo-controlled trial of vitamin $\mathrm{D}$ supplementation in adolescents and young adults with Juvenile-onset SLE: Improvement in disease activity and fatigue scores. Arthritis Care Res (Hoboken). 2015 May 18. doi: 10.1002/acr.22621. [Epub ahead of print]

33. Linker-Israeli M, Elstner E, Klinenberg JR, Wallace DJ, Koeffler HP. Vitamin D(3) and its synthetic analogs inhibit the spontaneous in vitro immunoglobulin production by SLE-derived PBMC. Clin Immunol. 2001;99:82-93.

34. López-Robles $\mathrm{C}$, Rios-Fernández $\mathrm{R}$, Callejas-Rubio JL, Ortego-Centeno N. Vitamin D deficiency in a cohort of patients with systemic lupus erythematous from the South of Spain. Lupus. 2011;20(3):330-1.

35. Mandal M, Tripathy R, Panda AK, Pattanaik SS, Dakua S, Pradhan AK, et al. VitaminD levels in Indian systemic lupus erythematosus patients: association with disease activity index and interferon alpha. Arthritis Res Ther. 2014;16(1):R49.

36. Marques CDL, Dantas AT, Fragoso TS, Duarte ÂLBP. The importance of vitamin D levels in autoimmune diseases. Bras J Rheumatol. 2010;50(1):67-80.

37. Mok CC, Birmingham DJ, Ho LY, Hebert LA, Song $\mathrm{H}$, Rovin BH. Vitamin D deficiency as marker for disease activity and damage in systemic lupus erythematosus: a comparison with anti-dsDNA and anti-C1q. Lupus. 2012;21:36-42.

38. Mok CC, Birmingham DJ, Leung HW, Hebert LA, Song H, Rovin BH. Vitamin D levels in Chinese patients with systemic lupus erythematosus: relationship with disease activity, vascular risk factors and atherosclerosis. Rheumatology (Oxford). 2012;51(4):644-52.

39. Munoz-Ortego J, Torrente-Segarra V, Prieto-Alhambra D, Salman-Monte T, Carbonell-Abello J. Prevalence and predictors of vitamin D deficiency in non-supplemented women with systemic lupus erythematosus in the Mediterranean region: a cohort study. Scand J Rheumatol. 2012;41(6):472-5.

40. Penna G, Adorini L. Alpha,25-dihydroxyvitamin D3 inhibits differentiation, maturation, activation, and survival of dendritic cells leading to im- paired alloreactive T cell activation. J Immunol. 2000;164(5):2405-11.

41. Petri M, Bello KJ, Fang H, Magder LS. Vitamin D in systemic lupus erythematosus: modest association with disease activity and urine protein/creatinine ratio. Arthritis Rheum. 2013;65(7):1865-71.

42. Piantoni S, Andreoli L, Scarsi M, Zanola A, Dall' Ara F, Pizzorni C, et al. Phenotype modifications of T-cells and their shift toward a Th2 response in patients with systemic lupus erythematosus supplemented with different monthly regimens of vitamin D. Lupus. 2015; 24(4-5):490-8.

43. Prietl B, Treiber G, Pieber TR, Amrein K. Vitamin $\mathrm{D}$ and immune function. Nutrients. 2013;5(7):2502-21.

44. Reynolds JA, Haque S, Berry JL, Pemberton P, Teh LS, Ho P, et al. 25-Hydroxyvitamin D deficiency is associated with increased aortic stiffness in patients with systemic lupus erythematosus. Rheumatology. 2012;51:544-51.

45. Ritterhouse LL, Crowe SR, Niewold TB, Kamen DL, Macwana SR, Roberts VC, et al. Vitamin D deficiency is associated with an increased autoimmune response in healthy individuals and in patients with systemic lupus erythematosus. Ann Rheum Dis. 2011;70(9):1569-74.

46. Rolf L, Muris AH, Hupperts R, Damoiseaux J. Vitamin D effects on B cell function in autoimmunity. Ann N Y Acad Sci. 2014;1317:84-91.

47. 47. Ruiz-Irastorza G, Egurbide MV, Olivares N, Martinez-Berriotxoa A, Aguirre C. Vitamin D deficiency in systemic lupus erythematosus: prevalence, predictors and clinical consequences. Rheumatology. 2008;47:920-3.

48. Ruiz-Irastorza G, Gordo S, Olivares N, Egurbide MV, Aguirre C. Changes in vitamin D levels in patients with systemic lupus erythematosus: Effects on fatigue, disease activity, and damage. Arthritis Care Res (Hoboken). 2010;62(8):1160-5.

49. Sakem B, Nock C, Stanga Z, Medina P. Nydegger UE, Risch M. et al., Serum concentrations of 25-hydroxyvitamin D and immunoglobulins in an older Swiss cohort: results of the Senior Labor Study. BMC Med. 2013;11:176.

50. Schneider L, Colar da Silva AC, Werres Junior LC, Alegretti AP, Pereira dos Santos AS, Santos M, et al. Vitamin D levels and cytokine profiles in patients with systemic lupus erythematosus. Lupus. 2015;24(11):1191-7. 
51. Szodoray P, Tarr T, Bazso A, Poor G, Szegedi G, Kiss E. The immunopathological role of vitamin D in patients with SLE: data from a single centre registry in Hungary. Scand J Rheumatol. 2011;40(2):122-6.

52. Terrier B, Derian N, Schoindre Y, Chaara W, Geri $\mathrm{G}, \mathrm{Zahr} \mathrm{N}$, et al. Restoration of regulatory and effector T cell balance and B cell homeostasis in systemic lupus erythematosus patients through vitamin D supplementation. Arthritis Res Ther. 2012;14(5):R221.

53. 53. Thudi A, Yin S, Wandstrat AE, Li QZ, Olsen NJ. Vitamin D levels and disease status in Texas patients with systemic lupus erythematosus. Am J Med Sci. 2008;335(2):99-104.

54. Toloza SM, Cole DE, Gladman DD, Ibañez D, Urowitz MB. Vitamin D insufficiency in a large female SLE cohort. Lupus. 2010;19(1):13-9.

55. Toubi E, Shoenfeld $Y$. The role of vitamin $D$ in regulating immune responses. Isr Med Assoc J. 2010;12:174-5.

56. Wright TB, Shults J, Leonard MB, Zemel BS, Burnham JM. Hypovitaminosis D is associated with greater body mass index and disease activity in pediatric systemic lupus erythematosus. J Pediatr. 2009 Aug;155(2):260-5.

57. Wu PW, Rhew EY, Dyer AR, Dunlop DD, Langman CB, Price H, et al. 25-hydroxyvitamin D and cardiovascular risk factors in women with systemic lupus erythematosus. Arthritis Rheum. 2009;61:1387-95.

58. Yap KS, Morand EF. VitaminD and systemic lupus erythematosus: continued evolution. Int J Rheum Dis. 2015;18(2):242-9.

59. Yeap SS, Othman AZ, Zain AA, Chan SP. Vitamin $D$ levels: its relationship to bone mineral density response and disease activity in premenopausal Malaysian systemic lupus erythematosus patients on corticosteroids. Int J Rheum Dis. 2012;15(1):17-24.

60. Yu S, Cantorna MT. The vitamin D receptor is required for iNKT cell development. Proc Natl Acad Sci USA. 2008;105:5207-12. 